\title{
Characterization of new cell line stably expressing CHI3L1 oncogene
}

\author{
O. V. Balynska, V. P. Baklaushev', P. O. Areshkov, S. S. Avdieiev, \\ O. I. Boyko, V. P. Chekhonin', V. M. Kavsan \\ Institute of Molecular Biology and Genetics, NAS of Ukraine \\ 150, Akademika Zabolotnoho Str., Kyiv, Ukraine, 03680 \\ ${ }^{1}$ V. P. Serbsky National Research Centre for Social and Forensic Psychiatry, RUSA Ministry of Health \\ 23, Kropotkinsky lane, Moscow, Russian Federation \\ 1.v.balynskaya@gmail.com
}

\begin{abstract}
Aim. To characterize the immortalized 293 cell line after stable transfection with human oncogene (CHI3L1). Methods. 293 cells, stably transfected with pcDNA3.1_CHI3L1, and 293 cells, stably transfected with pcDNA3.1 as a negative control, were used throughout all experiments. The clones of CHI3L1-expressing 293 cells and 293 cells, transfected with pcDNA3.1, were analyzed by immunofluorescence and confocal microscopy. Cell proliferation was measured using MTT assay; analyses of ERK1/2 and AKT activation and their cellular localization were performed with anti-phospho-ERK and anti-phospho-AKT antibodies. Specific activation of MAP and PI3 kinases was measured by densitometric analysis of Western-blot signals. Results. The obtained results show quite modest ability of CHI3L1 to stimulate cell growth and reflect rather an improved cellular plating efficiency of the 293 cells stably transfected with pcDNA3.1_CHI3L1 as compared to the 293 cells transfected with an «empty» vector. ERK1/2 and AKT are activated in the 293_CHI3L1 cells. In these cells phosphorylated ERK1/2 were localized in both cell cytoplasm and nuclei while AKT only in cytoplasm. The 293_CHI3L1 cells differed from the 293 cells, transfected with an "empty" vector, in their size and ability to adhere to the culture plates. Conclusions. The overexpression of CHI3L1 is likely to have an important role in tumorigenesis via a mechanism which involves activation of PI3K and ERK1/2 pathways. The tumors which can be induced by orthotopic implantation of the transformed human cells with overexpressed human oncogene CHI3L1 into the rat brain can be used as a target for anticancer drug development.
\end{abstract}

Key words: chitinase 3-like 1 protein (CHI3L1), brain tumor, MAP kinase, PI3 kinase.

Introduction. Mouse models of human cancer have been instructional in understanding the basic principles of cancer biology. Recently, we have reported the development of a new method to induce tumors in adult immunocompetent rat brains by the 293 cells stably producing chitinase 3-like 1 oncoprotein (CHI3L1) (Kavsan et al., in press).

CHI3L1 is a member of mammalian chitinase-like proteins [1-3], it is also named YKL-40 based on its three N-terminal amino acids tyrosine $(\mathrm{Y})$, lysine $(\mathrm{K})$

(C) Institute of Molecular Biology and Genetics, NAS of Ukraine, 2011 and leucine (L) and molecular mass of $40 \mathrm{kDa}$ [4], or human cartilage glycoprotein-39 (HC gp-39) [1], 38-kDa heparin-binding glycoprotein (Gp38k) [5], breast regression protein $39 \mathrm{kDa}$ (brp-39) [6], and Chondrex [7]. The gene for human CHI3L1 is localized on chromosome 1 and the crystal structure of human CHI3L1 has been described $[8,9]$.

Increased level of serum CHI3L1 has been suggested as a robust biomarker of various inflammatory/fibrotic diseases [10].

The increased CHI3L1 expression has been documented in various malignancies [11] and a number of 
cancer cell lines $[4,6,12]$. Previously, in an effort to identify genes which could be used as molecular markers of glial tumors, we found CHI3LI as one of the most overexpressed in glioblastomas [13]. Furthermore, CHI3L1 plays a role in angiogenesis by stimulating the migration and reorganization of vascular endothelial cells $[14,15]$. CHI3L1 also stimulates the migration of endothelial cells and promotes the migration and adhesion of vascular smooth muscle cells $[15,16]$.

Here we describe further characterization of a new 293 cell line stably producing oncoprotein CHI3L1.

Materials and methods. Cells. The 293 cells (Human Embryonic Kidney 293 cells, also often referred to HEK293, or less precisely as HEK cells), were kindly provided by Prof. V. Filonenko; 293 cells, stably transfected with $p c D N A 3.1$ («empty» vector) were kindly provided by Dr. V. Grishkova (IMBG, Ukraine); the 293 cells, stably expressing CHI3L1 (293_CHI3L1) we obtained earlier (Kavsan et al., in press).

The clones of 293_CHI3L1 cells were obtained by limiting dilution cloning of the 293 cells, stably expressing CHI3L1. The presence of CHI3L1 in the cloned cells was evaluated by immunofluorescence and confocal microscopy. For this purpose the CHI3L1 expressing clones of 293 cells and 293 cells, transfected with an «empty» vector were seeded on coverslips and allowed to grow to near-confluence. The cells were washed in cold phosphate-buffered saline (PBS), fixed with $4 \%$ paraformaldehyde and permeabilized with Triton X100, washed three times for 5 min each with PBS, and blocked with $5 \%$ horse serum («Sigma», USA) in PBS (blocking buffer) for $30 \mathrm{~min}$ at room temperature. Incubations were performed at room temperature with antibodies diluted in blocking buffer. Slides were mounted using PVA-DABCO («Sigma») and images were captured with Zeiss LSM 510 Meta confocal microscope (Germany). Presence of CHI3L1 in the conditioned medium from the cloned cells was determined after $24 \mathrm{~h}$ of cell starvation by Western blotting, 1/20 part of the cell conditioned medium was used from $3 \mathrm{~cm}$ well.

Proteins and antibodies. The goat polyclonal antibodies against human CHI3L1 (S-18) were purchased from «Santa Cruz Biotechnology» (USA), p44/42 mitogen activated protein (MAP) (extracellular signalregulated kinase (ERK1/2)) (L34F12) Mouse mAb («Cell Signaling Technology», USA); (ERK1) (K-23) rabbit polyclonal IgG («Santa Cruz»); Anti-phosphoAkt1/PKB $\alpha$ (Ser473), clone 11E6, mouse monoclonal IgG («Millipore», USA); Anti-Mouse IgG $(\mathrm{H}+\mathrm{L})$, HRP Conjugate, Anti-Rabbit IgG $(\mathrm{H}+\mathrm{L})$, HRP Conjugate («Promega», USA), and Rabbit anti-goat IgG $(\mathrm{H}+$ $+\mathrm{L}$ ), HRP Conjugate («Invitrogen», USA) used in Western blot as well as goat anti-rabbit Alexa Fluor 488 and rabbit anti-goat Alexa Fluor 633 antibodies used in immunofluorescence were from «Invitrogen».

Cell proliferation assay. The clone 1 of 293 cells stably expressing CHI3L1, and the 293 cells, stably transfected with pcDNA3.1 were seeded in quadruplicates into 96 well plate at density $2 \cdot 10^{3}$ cells/well and grown in DMEM, supplemented with $10 \%$ FBS, $300 \mu \mathrm{g} / \mathrm{ml}$ geneticin G418 sulphate and $100 \mu \mathrm{g} / \mathrm{ml}$ penicillin $/ 100$ units $/ \mathrm{ml}$ streptomycin (PAA, Austria) for 5 days. Cell proliferation was measured using 3-(4,5-dimethylthiazol-2-yl)-2,5-diphenyltetrazolium bromide (MTT) («Sigma») at days 2, 3, 4 and 5, of seeding.

Analysis of ERK1/2 and AKT activation. For investigation of ERK1/2 phosphorylation the 293 CHI3L1 cells (clone 1) and 293 cells, stably transfected with an «empty» vector, were seeded into 6-well tissue culture plates in DMEM contained $10 \%$ FBS and allowed to grow to near-confluence. Cells were serum-starved for $24 \mathrm{~h}$. Cell layers were washed twice in ice-cold PBS and whole cell lysates were mixed with $2 \times$ Laemmli sample buffer, boiled, proteins were resolved by $10 \%$ sodium dodecyl sulphate-polyacrylamide gel electrophoresis (SDS-PAGE), and transferred to the nitrocellulose membrane.

Membranes were blocked for $1 \mathrm{~h}$ at room temperature with $5 \%$ powdered skim milk in Tris buffered saline (TBS) with $0.05 \%$ Tween-100 (TBST), reacted with anti-phospho-ERK or anti-phospho-AKT at $4{ }^{\circ} \mathrm{C}$ overnight, and then incubated with HRP-anti-mouse IgG for $1 \mathrm{~h}$. Blots were developed with an ECL detection system. Then membranes were incubated in stripping buffer ( $0.5 \mathrm{M} \mathrm{NaCl}, 0.2 \mathrm{M}$ Gly, $\mathrm{pH} 2.5)$ for $15 \mathrm{~min}$ at $70{ }^{\circ} \mathrm{C}$, washed twice in TBST, blocked, and incubated with anti-ACTB for $1 \mathrm{hr}$ at room temperature. After incubation with HRP-anti-rabbit IgG for $1 \mathrm{~h}$, ACTB was detected with ECL. Specific activation of MAP kinases was measured by densitometric analysis of Western-blot signals using Scion Image 1.62c program $(\mathrm{NIH}$ ImageJ; NIH, USA). 
To investigate the localization of phosphorylated ERK1/2 and phosphorylated AKT, the 293 cells, stably expressing CHI3LI (clone 1), and the 293 cells, stably transfected with an «empty» vector, were prepared as described above. The cells were washed in cold PBS, fixed with $10 \%$ paraformaldehyde and permeabilized in $-20{ }^{\circ} \mathrm{C}$ methanol, washed three times for $5 \mathrm{~min}$ each with PBS and blocked with blocking buffer ( $2 \%$ bovine serum albumin, BSA) in PBS for $30 \mathrm{~min}$ at room temperature. Incubations were performed at room temperature with antibodies diluted in blocking buffer. Slides were mounted using PVA-DABCO («Fluka, Switzerland») and images were captured with a Zeiss LSM 510 Meta confocal microscope. All images represent a single confocal section, taken from the bottom surface of the cells being analyzed.

Results and discussion. The significant increasing of $C H I 3 L 1$ gene expression was shown for a number of tumors [11] including glioblastomas in our and other laboratories [13, 17, 18]. These data were obtained mostly by Serial Analysis of Gene Expression (SAGE) and microarray analysis or polymerase chain reaction (PCR) and were presented mostly as an average gene expression for a given group of patients. The results of CHI3L1 RNA Northern hybridization which were performed in our lab as described earlier [13,18] are summarized in Fig. 1 indicating a substantial increase of CHI 3 L 1 expression in anaplastic astrocytomas - World Health Organization (WHO) III stage of malignancy and glioblastomas - WHO IV stage of malignancy. At the same time $C H I 3 L 1$ expression is much lower in diffuse astrocytomas (WHO II stage of malignancy) and in normal adult human brain. However, there appears to be also significant (about $20 \%$ ) overlap of the levels in individual samples of tumor and normal brain. Recently it has been shown that the expression of $\mathrm{CHI} 3 \mathrm{LI}$ does not increase in proneural subtype of glioblastoma comprising up to $30 \%$ of all glioblastomas [19], and the patients with such tumors experience significantly improved outcome. So, the absence of $\mathrm{CHI} 3 \mathrm{~L} 1$ expression revealed by Northern hybridization could serve as a prognostic marker.

The clones of 293_CHI3L1 cells were obtained by limiting dilution cloning of the 293 cells, stably expressing CHI3L1. Overproduction of CHI3L1 in the cloned cells was confirmed by Western blot and immunofluo-

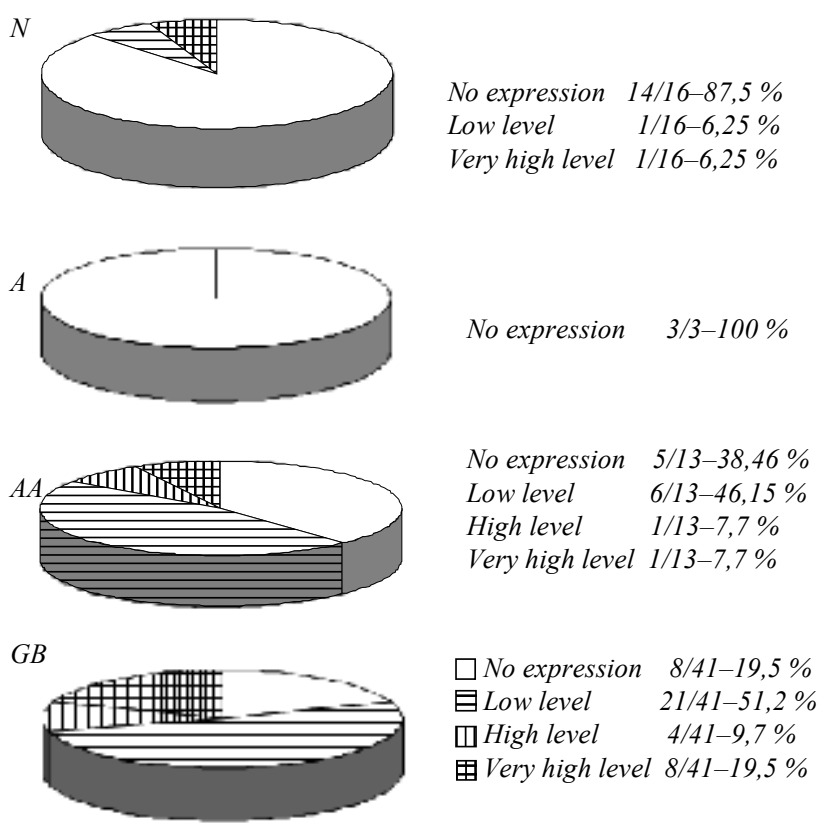

Fig. 1. Results of $C H I 3 L 1$ Northern blot analysis in human glial tumors and normal brain. $N$-normal brain; $A$ - astrocytoma; $A A$ - anaplastic astrocytoma; $G B$ - glioblastoma

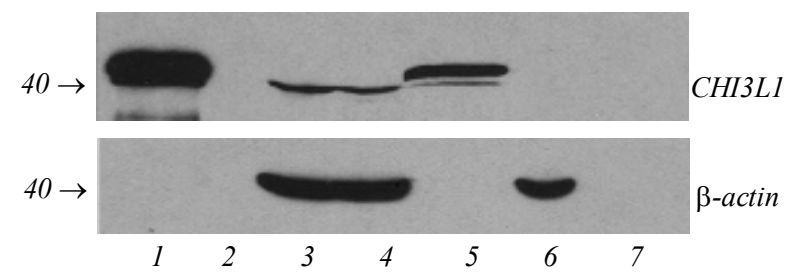

Fig. 3. Western blot analysis of CHI3L1 protein secretion. The conditioned medium in the absence of serum were collected after 24-h culture for analyzing the level of CHI3L1 secreted from 293 cells, stably expressing CHI3L1 and 293 cells, stably transfected with an «empty» vector. Cell lysates were subjected also to the testing of actin expression; 1 - conditioned medium from MG-63 cells (positive control); 2 empty track; 3 - 293 cells stably expressing CHI3L1; 4 - 293 cells, stably expressing $C H I 3 L 1$ in the absence of serum; 5 - conditioned medium from 293 cells, stably expressing CHI3L1; 6 - 293 cells, stably transfected with an «empty» vector; 7 - conditioned medium from 293 cells, stably transfected with an «empty» vector

rescent analysis (Fig. 2, see inset). Western blot analysis revealed CHI3L1 in the 293_CHI3L1 cell conditioned medium, showing that CHI3L1 is a secreted protein. Previously it was shown, that CHI3L1 was secreted in large amount by osteosarcoma cell line MG-63 [7]. As it is possible to see, the 293_CHI3L1 cells also secrete CHI3L1 but at lower level than MG-63 in the same culturing conditions (Fig. 3).

The results presented in the Fig. 4 show the ability of CHI3L1 to promote cellular proliferation. However, 

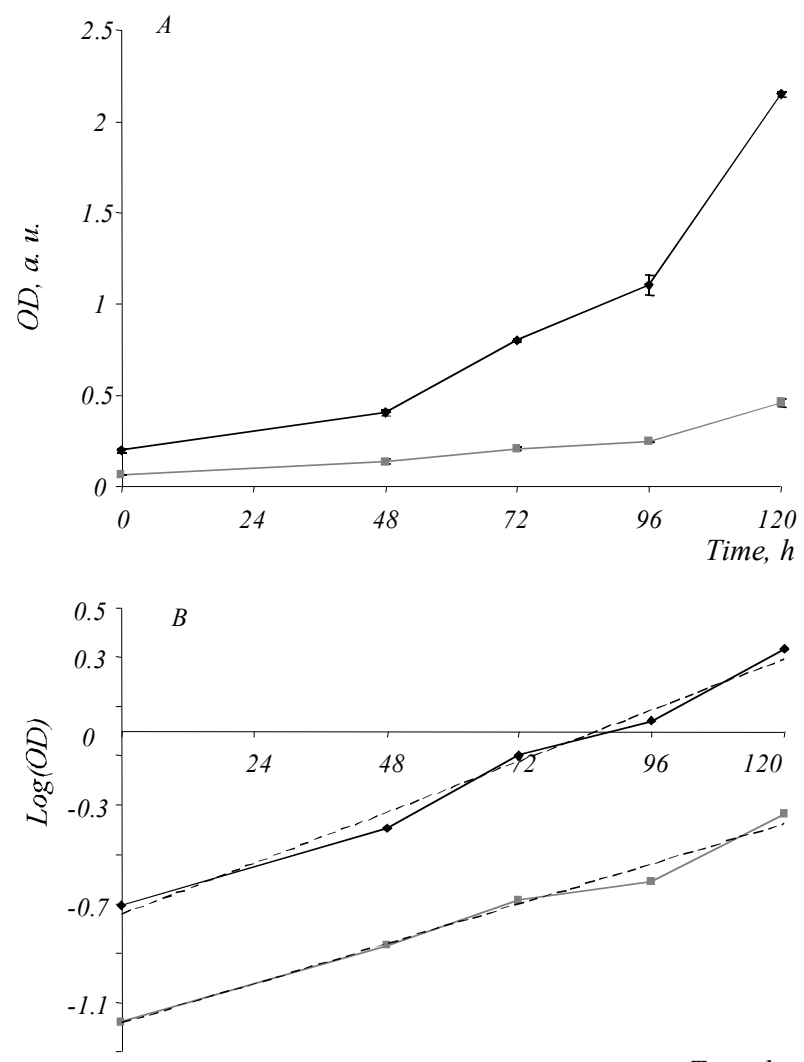

Time, $h$

Fig. 4. Proliferation of 293 clones stably expressing CHI3L1: $A$ - standard coordinates; $B$ - semi-logarithmic scale. - -293 cells, transfected with «empty» vector, -293 cells, stably expressing CHI3L1 (clone 1), $\cdots$ - trend line. Proliferation was measured by fluorescence after $3 \mathrm{~h}$ of cells exposure to MTT reagent. The data shown are the means \pm S.D. from four experiments for each cell line

the ability of CHI3L1 to stimulate cell growth when produced endogenously was quite modest, what is consistent with the data of Shao et al. [20]. Five days after the equal numbers of cells were plated, there were approximately 1,6-fold as many the CHI3L1-expressing clones as parental cells. The major difference was an improved plating efficiency with the greater number of cells present at the initial time point of $12 \mathrm{~h}$ (day 0). After performing linear regression analysis for log scale graph the slopes were 0,0086 for the 293_CHI3L 1 cells and $-0,0067$ for the 293_3.1 cells, resulting in 1,3-fold increase in cell growth rate. Thereafter, we suppose that the effect of $C H I 3 L 1$ transfection was mostly on cellular plating efficiency and perhaps also on clonogenicity, a similar cellular growth phenomenon.

The 293_CHI3L1 cloned cells were increased in size as compared to the «empty» vector transfected human 293 cells, both cell lines were oblong but the 293_CHI3L1 cloned cells were more prone to grow in well-defined monolayer while the «empty» vector transfected human 293 cells tended to grow in foci (Fig. 5, see inset).

The MAPK and phosphoinositide 3-kinase (PI3K) pathways are strongly associated with cell survival. ERK1 and ERK2 were identified as growth factor-stimulated protein kinases phosphorylating microtubule-associated protein-2 (MAP-2) and myelin basic protein (MBP). Activation of ERK1/2 is involved in many cellular responses such as cell motility, proliferation, differentiation and survival [21]. We found that overproduction of CHI3L1 in the cells stably transfected with $C H I 3 L 1$ induced activation of ERK1/2 with equivalent cytoplasmic and nuclear localization. Moreover, AKT the main component of PI3K signaling pathway, was also phosphorylated in these cells and confocal laser scanning microscopy showed phosphorylated AKT to be located in the cytoplasm (Fig. 6, see inset). Although AKT is best known for promoting cell survival and growth through pathways parallel to ERK's control over cell proliferation, AKT activation can also stimulate proliferation through multiple downstream targets impinging on the cell-cycle regulation [22]. It has been reported that AKT migrated into the nucleus in response to a variety of stimuli, where it can block FOXO-mediated transcription of target genes that promote apoptosis, cell-cycle arrest, and metabolic processes [23]. On the other hand, a function of AKT is to phosphorylate and inhibit proapoptotic components of the intrinsic cell death machinery within the cytoplasm [24]. It is possible to hypothesize, that in the case of the 293_CHI3L 1 cells AKT can play this role. So, CHI3L1 has a different effect on cellular localization of ERK $1 / 2$ and AKT. The results suggest that biological effects of CHI3L1 are mediated by association with unknown cell surface receptor promoting proliferation of the 293 cells through Ras/MAPK/AKT pathways and support a role of CHI3L1 in the malignant phenotype as a cellular survival factor.

It is interesting that the 293 cells (HEK293) were obtained by transformation of the human embryonic kidney cell culture with sheared adenovirus 5 DNA [25]. The observation that the 293 cells stain strongly and specifically with antibodies to several NF proteins, which are generally thought of as excellent markers for 
neuronal lineage cells, stimulated detailed DNA microarray analysis of the 293 cells. More than 60 mRNA normally expressed specifically in neuronal cells were detected in the 293 cells by this approach. Microarray analysis of the 293 cells using Affymetrix and Clontech arrays revealed also mRNAs encoding many other proteins normally expressed in neuronal lineage cells. The pattern of expression was quite similar to that seen in the PC12 and Ntera-2 cells, which also express a mix of neurofilament subunits and two basic keratins. So, the 293 cells were similar in several respects to the two well defined neuronal lineage cell lines [26].

Tumor formation by the 293 cells stably expressing CHI 3 L 1 in rat brains strongly suggests that this gene is likely to be critical in the tumor development, and tumors which can be induced after orthotopic implantation of transformed human cells with overexpressed human oncogene $\mathrm{CHI} 3 \mathrm{~L} 1$ in the rat brain can be used as a target for anticancer drug development.

Acknowledgments. We thank Dr. S. Karakhim for providing expertise and access to Zeiss confocal microscope, Dr. I. Skrypkina for help in immunofluorescence analysis and A. Iershov for the help of manuscript preparation. This work was supported in part by National Academy of Sciences of Ukraine in frames of the program «Fundamental grounds of molecular and cell biotechnologies» and by Science and Technology Center in Ukraine, project 4688.

О. В. Балинська, В. П. Баклаушев, П. О. Арешков, С. С. Авдєєв, О. І. Бойко, В. П. Чехонін, В. М. Кавсан

Характеристика нової клітинної лінії, що стабільно експресує онкоген CHI3LI

\section{Резюме}

Мета. Охарактеризувати імморталізовану клітинну лінію 293 після стабільної трансфекиї онкогена CHI3L1. Методи. Клітини 293, стабільно трансфековані рсDNA3.1_CHI3L1, та клітини 293, стабільно трансфековані рсDNA3.1 як негативний контроль, використано в усіх експериментах. Клони 293 експресуючих CHI3L1 клітин та клітини 293, трансфековані «порожнім» вектором, проаналізовано методами імунофлуоресиениії та конфокальної мікроскопії. Клітинну проліферачію визначено за допомогою MTT, активачію ERK1/2 i AKT та їхню локалізацію в клітинах - із застосуванням анти-фосфо-ERK- та анти-фосфо-АKT-антитіл. Специфічну активацію кіназ МАP $i$ PI3 визначено денситометричним аналізом Вестерн-блот сигналів. Результати. Отримані результати демонструють помірну здатність СНI3L1 стимулювати клітинний ріст, але відображають скоріше підвищену здатність до прикріплення 293 клітин, стабільно трансфекованих рсDNA3.1_CHI3L1 порівняно з клітинами 293, трансфекованими «порожнім» вектором. У 293 CHI3L1 клітинах ERK1/2 ma AKT перебувають в активованому стані. У ичих клітинах фосфорильовані ERK1/2 локалізовані як у цитоплазмі, так $і$ в ядрі, тоді як AKT - лише в ичитоплазмі. 293_CHI3L1-клітини відрізняються від клітин 293_pcDNA3.1 за морфологією та їхньою здатністю до прикріплення до культуральних чашок. Висновки. Надекспресія CHI3L1, очевидно, має важливе значення в пухлиноутворунні і опоседковується активаиією PIЗK- і МАРК- сигнальних шляхів. Пухлини, спричинені ортотопічною імплантацією трансформованих клітин людини з надекспресованим CHI3L1 умозок щурів, стають вірогідною міменню для антиракової терапї.

Ключові слова: хітиназа 3-подібний білок 1 (СНI3L1), пухлини головного мозку, МАР-кіназа, РІ3-кіназа.

Е. В. Бальлская, В. П. Баклаушев, П. О. Арешков, С. С. Авдеев, О. И. Бойко, В. П. Чехонин, В. М. Кавсан

Характеристика новой клеточной линии, стабильно экспрессирующей онкоген $C H I 3 L 1$

Резюме

Цель. Охарактеризовать иммортализованную клеточную линию 293 после стабильной трансфекции онкогена CHI3L1. Методы. Клетки 293, стабильно трансфецированные рсDNA3.1_CHI3L1, и клетки 293, стабильно трансфецированные рсDNA3.1 в качестве отрицательного контроля, использованы во всех эксперименmax. Клоны 293_CHI3L1 и клетки 293_рсDNA3.1 анализировали методами иммунофлюоресценции и конфокальной микроскопии. Клеточную пролиферацию определяли с помощью МТT, активациию и локализацию ЕRK1/2 и АКТ анализировали с применением анти-фосфо-ЕRK- и анти-фосфо-АKT-антител. Специфическую активацию МАР- и РІ3-киназ определяли денситометрическим анализом Вестерн-блот сигналов. Результаты. Полученные результаты демонстрируют умеренную способность СНI3L1 $\mathrm{cmu-}$ мулировать клеточный рост и отражают скорее повыщенную способность к прикреплению клеток, стабильно трансфециирванных рсDNA3.1_CHI3L1 по сравнению с 293-клетками, трансфецированнылми «пустымм» вектором. ЕRK1/2 и AKT в клетках 293 CHI3L1 находятся в активированном состоянии. В этих клетках фосфорилированные ERK1/2 локализованы как в ичитоплазме, так и в ядре, в то время как АКТ - только в ичтоолазме. Клетки 293_CHI3L1_отличаются от клеток 293 рсDNA3.1 по морфологии и способности прикрепления к культуральным чашкам. Выводы. Сверхэкспрессия CHI3L1, очевидно, имеет важное значение в опухолеобразовании и опосредуется активацией $\mathrm{PI} \mathrm{K}$ и МАРК-сигнальных путей. Опухоли, которые индуцируются ортотопической имплантацией трансформированных человеческих клеток со сверхэкспрессированным CHI3L1 в мозг крыс, могут служить мишенью для антираковой терапии.

Ключевые слова: хитиназа 3-подобный белок 1 (CHI3L1), опухоли головного мозга, МАР-киназа, РІЗ-киназа.

\section{REFERENCES}

1. Hakala B. E., White C., Recklies A. Human cartilage gp-39, a major secretory product of articular chondrocytes and synovial cells, is a mammalian member of a chitinase protein family // $\mathrm{J}$. Biol. Chem.-1993.-268, N 34.-P. 25803-25810.

2. Rehli M., Krause S. W., Andreesen R. Molecular characterization of the gene for human cartilage gp-39 (CHI3L1), a member 
of the chitinase protein family and marker for late stages of macrophage differentiation // Genomics.-1997.-43, N 2.- P. 221225.

3. Funkhouser J. D., Aronson N. N. Jr. Chitinase family GH18: evolutionary insights from the genomic history of a diverse protein family // BMC Evol. Biol.-2007.-7.- P. 96.

4. Johansen J. S., Williamson M. K., Rice J. S., Price P. A. Identification of proteins secreted by human osteoblastic cells in culture // J. Bone Miner. Res.-1992.-7, N 5.-P. 501-512.

5. Shackelton L. M., Mann D. M., Millis A. J. Identification of a 38$\mathrm{kDa}$ heparin-binding glycoprotein (gp38k) in differentiating vascular smooth muscle cells as a member of a group of proteins associated with tissue remodeling // J. Biol. Chem.-1995.-270, N 22.-P. 13076-13083.

6. Morrison B. W., Leder P. neu and ras initiate murine mammary tumors that share genetic markers generally absent in c-myc and int-2-initiated tumors // Oncogene.-1994.-9, N 12.-P. 34173426 .

7. Harvey S., Weisman M., O'Dell J., Scott T., Krusemeier M., Visor J., Swindlehurst C. Chondrex: new marker of joint disease // Clin. Chem.-1998.-44, N 3.-P. 509-516.

8. Houston D. R., Recklies A. D., Krupa J. C., van Aalten D. M. F. Structure and ligand-induced conformational change of the 39$\mathrm{kDa}$ glycoprotein from human articular chondrocytes // J. Biol. Chem.-2003.-278, N 32.-P. 30206-30212.

9. Fusetti F., Pijning T., Kalk K. H., Bos E., Dijkstra B. W. Crystal structure and carbohydrate-binding properties of the human cartilage glycoprotein-39 // J. Biol. Chem.-2003.-278, N 39.P. 37753-37760.

10. Horbinski G., Wang G., Wiley C. A. YKL-40 is directly produced by tumor cells and is inversely linked to EGFR in glioblastomas // Int. J. Clin. Exp. Pathol.-2010.-3, N 3.-P. 226-237.

11. Johansen J. S. Studies on serum YKL-40 as a biomarker in diseases with inflammation, tissue remodelling, fibroses and cancer// Dan. Med. Bull.-2006.-53, N 2.-P. 172-209.

12. Junker N., Johansen J. S., Hansen L. T., Lund E. L., Kristjansen $P$. E. Regulation of YKL-40 expression during genotoxic or microenvironmental stress in human glioblastoma cells // Cancer Sci.-2005.-96, N 3.-P. 183-190.

13. Garifulin O. M., Shostak K. O., Dmitrenko V. V., Rozumenko V. D., Khomenko O. V., Zozulya Yu. A., Zehetner G., Kavsan V. M. The genes $S O X$-2 and $H C g p-39$ are overexpressed in astrocytic gliomas // Biopolym. Cell.-2002.-18, N 4.-P. 324-329.

14. Malinda K. M., Ponce L., Kleinman H. K., Shackelton L. M., Millis A. J. Gp38k, a protein synthesized by vascular smooth muscle cells, stimulates directional migration of human umbilical vein endothelial cells // Exp. Cell Res.-1999.-250, N 1.-P. 168173.

15. Saidi A., Javerzat S., Bellahce'ne A., De Vos J., Bello L., Castronovo V., Deprez M., Loiseau H., Bikfalvi A., Hagedorn M. Experimental anti-angiogenesis causes upregulation of genes associated with poor survival in glioblastoma // Int. J. Cancer.2008.-122, N 10.-P. 2187-2198.
16. Nishikawa K. C., Millis A. J. gp38k (CHI3L1) is a novel adhesion and migration factor for vascular cells // Exp. Cell Res.2003.-287, N 1.-P. 79-87.

17. Tanwar M. K., Gilbert M. R., Holland E. C. Gene expression microarray analysis reveals YKL-40 to be a potential serum marker for malignant character in human glioma // Cancer Res.2002.-62, N 15.-P. 4364-4368.

18. Shostak K., Labunskyy V., Dmitrenko V., Malisheva T., Shamayev M., Rozumenko V., Zozulya Y., Zehetner G., Kavsan V. HC gp-39 gene is upregulated in glioblastomas // Cancer Lett.2003.-198, N 2.-P. 203-210.

19. Noushmehr H., Weisenberger D. J., Diefes K., Phillips H. S., Pujara K., Berman B. P., Pan F., Pelloski C. E., Sulman E. P., Bhat K. P., Verhaak R. G., Hoadley K. A., Hayes D. N., Perou C. M., Schmidt H. K., Ding L., Wilson R. K., Phillips H. S., Pujara K., Berman B. P., Pan F., Pelloski C. E., Sulman E. P., Bhat K. P., Verhaak R. G., Hoadley K. A., Hayes D. N., Perou C. M., Schmidt H. K., Ding L., Wilson R. K., Van Den Berg D., Shen H., Bengtsson H., Neuvial P., Cope L. M., Buckley J., Herman J. G., Baylin S. B., Laird P. W., Aldape K; Cancer Genome Atlas Research Network. Identification of a $\mathrm{CpG}$ island methylator phenotype that defines a distinct subgroup of glioma // Cancer Cell.-2010.-17, N 5.-P. 510-522.

20. Shao R., Hamel K., Petersen L., Cao Q. J., Arenas R. B., Bigelow $C$., Bentley $B$., Yan $W$. YKL-40, a secreted glycoprotein, promotes tumor angiogenesis // Oncogene.-2009.-28, N 50.P. 4456-4468.

21. Raman M., Chen $W$., Cobb M. H. Differential regulation and properties of MAPKs // Oncogene.-2007.-26, N 22.-P. 3100-3112.

22. Manning B. D., Cantley L. C. AKT/PKB signaling: navigating downstream // Cell.-2007.-129, N 7.-P. 1261-1274.

23. Datta S. R., Brunet A., Greenberg M. E. Cellular survival: a play in three Akts // Genes Dev.-1999.-13, N 22.-P. 2905-2927.

24. Brunet A., Bonni A., Zigmond M. J., Lin M. Z., Juo P., Hu L. S., Anderson M. J., Arden K. C., Blenis J., Greenberg M. E. Akt promotes cell survival by phosphorylating and inhibiting a Forkhead transcription factor // Cell.-1999.-96, N 6.-P. 857868 .

25. Louis N., Evelegh C., Graham F. L. Cloning and sequencing of the cellular-viral junctions from the human adenovirus type 5 transformed 293 cell line // Virology.-1997.-233, N 2.-P. 423429.

26. Shaw G., Morse S., Ararat M., Graham F. L. Preferential transformation of human neuronal cells by human adenoviruses and the origin of HEK 293 cells // FASEB J.-2002.-16, N 8.P. 869-871.

27. Dmytrenko V., Kavsan V., Boyko O., Rymar V., Stepanenko O., Balynska O., Malysheva T., Rozumentko V., Zozulya Y. Expression of genes belonging to the IGF-system in glial tumors // Cytology and Genetics-2011.-45, N 5.-P. 41-57.

UDC 616-006.484; 577.212.3 Received 18.04.11 
Figure to article by V. V. Kostyukov

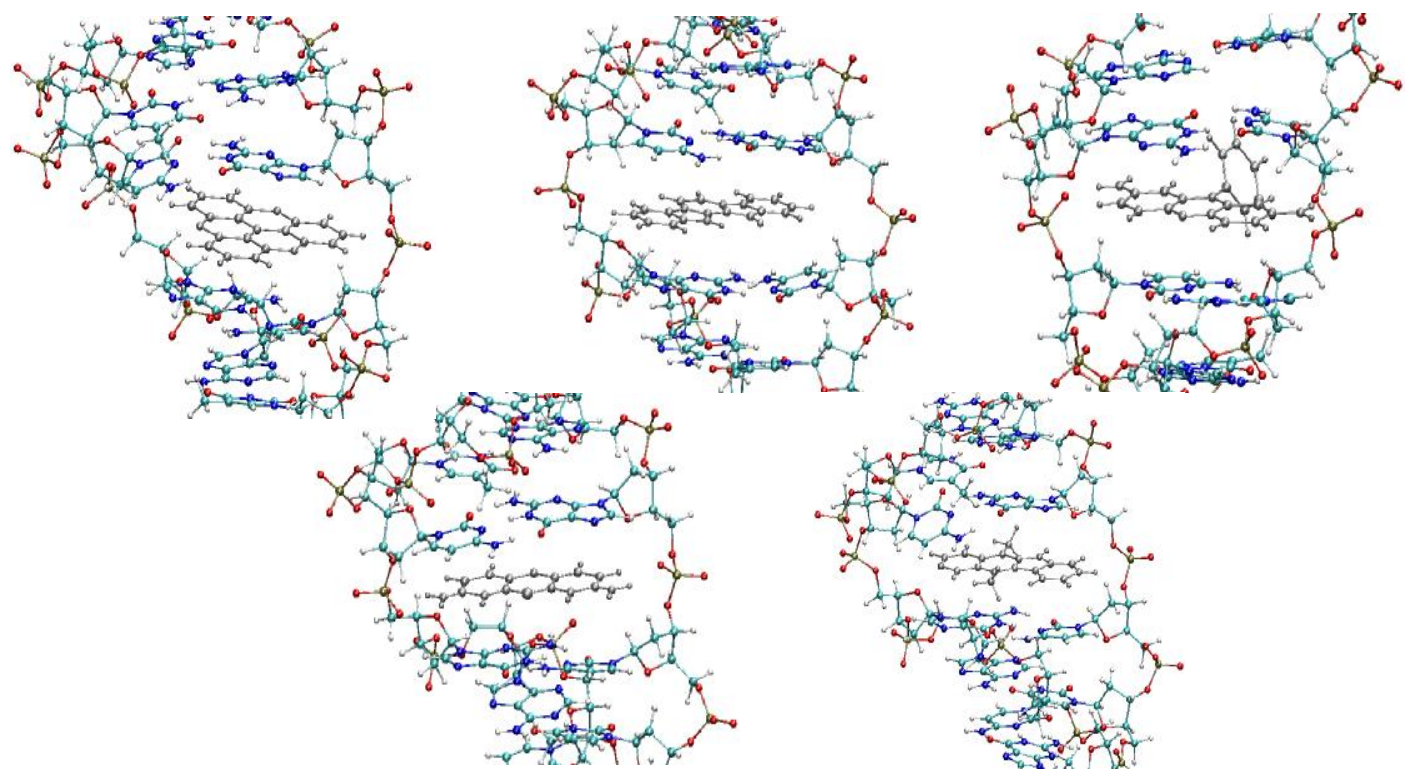

Рис. 2. Центральные участки расчетных структур комплексов гетероциклических лигандов с двуспиральной ДНК

Figures to article by O. V. Balynska et al.

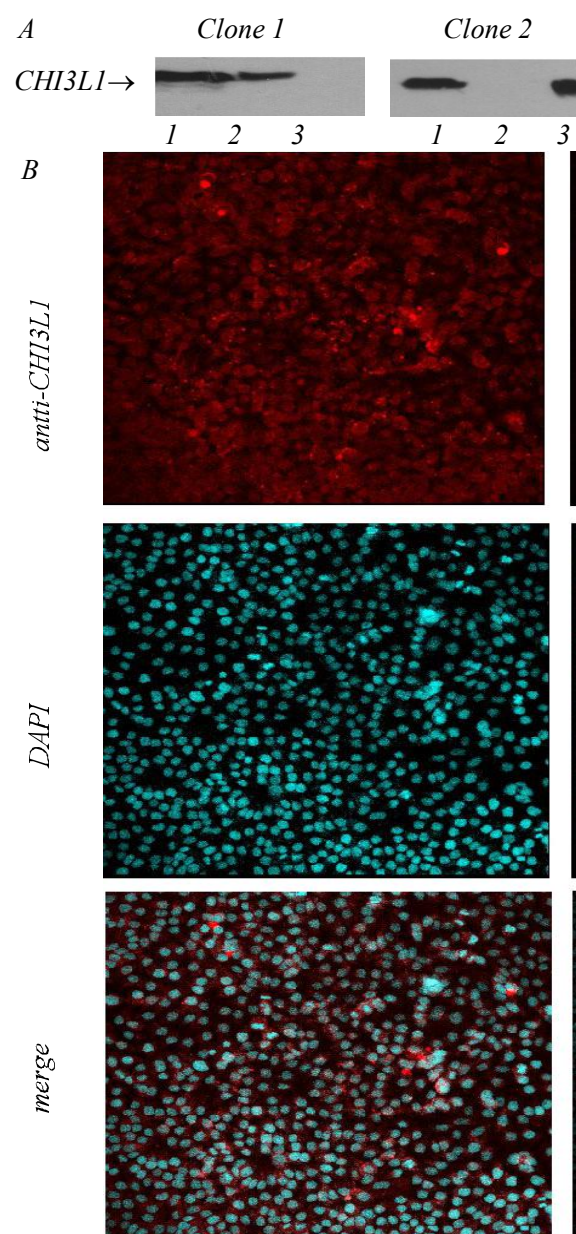

293 CHI3L1 cells (clone 1)
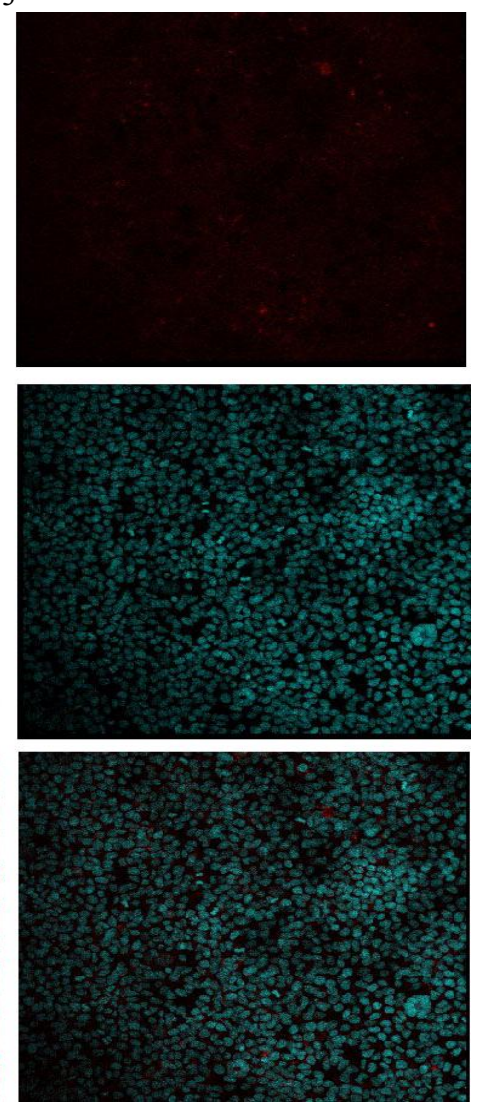

$293 \_p c D N A 3.1$ cells
Fig. 2. $A-$ Western blot analysis of CHI3L1 protein in 293_CHI3L1 cells clone 1: $1-293$ cells stably expressing CHI3L1; 2 - glioblastoma total lysate, prepared earlier; 3 - 293 cells, stably transfected with an «empty» vector clone $2: 1-293$ cells stably expressing CHI3L1; 2-293 cells, stably transfected with an «empty» vector; 3 - glioblastoma total lysate, prepared earlier [27]; $B$ - Immunofluorescent analysis of CHI3L1 in paraformaldehyde fixed 293 cells, stably expressing CHI3L1 (clone 1) and in 293 _pcDNA3.1 cells 
Figures to article by O. V. Balynska et al.
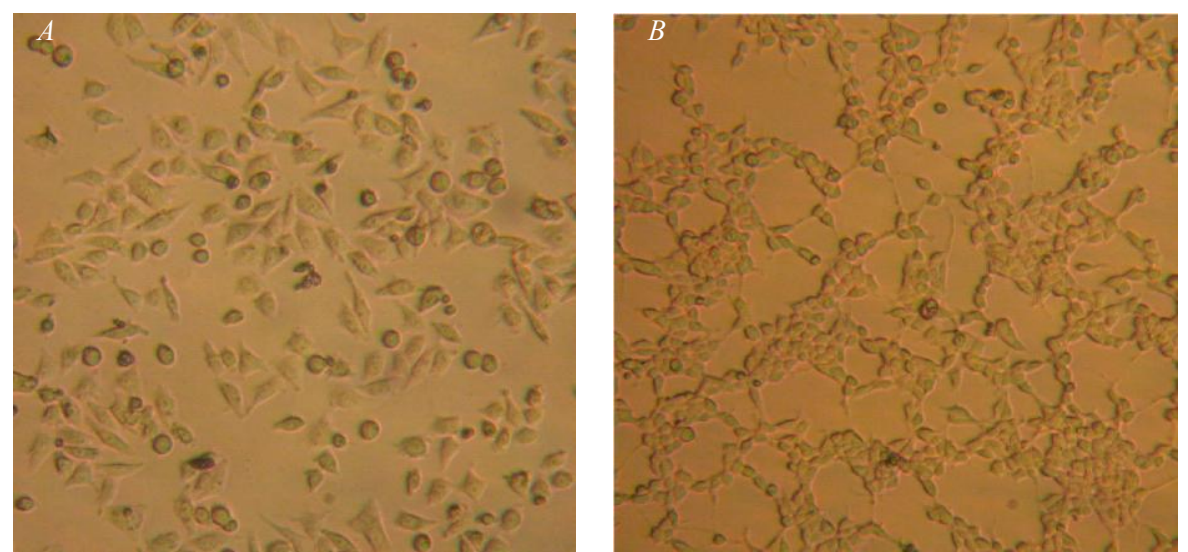

Fig. 5. Phase-contrast features of human 293 CHI3L1 cells $(A)$ and 293 cells, stably transfected with an «empty» $\operatorname{vector}(B)$

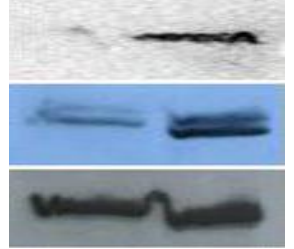

$1 \quad 2$ $p A K T$

$p E R K$

$\beta$-actin

Fig. 6. ERK1/2 and AKT activation: $A$ - Western blot analysis of AKT and ERK1/2 activation in starved 293 cells, stably transfected with an «empty» vector (1), 293 cells, stably expressing $C H I 3 L 1$ (2); $B$ - immunofluorescent analysis of ERK1/2 and $C$ - AKT activation in starved 293 cells, stably expressing CHI3L1 and 293 cells, stably transfected with an «empty» vector

$B$
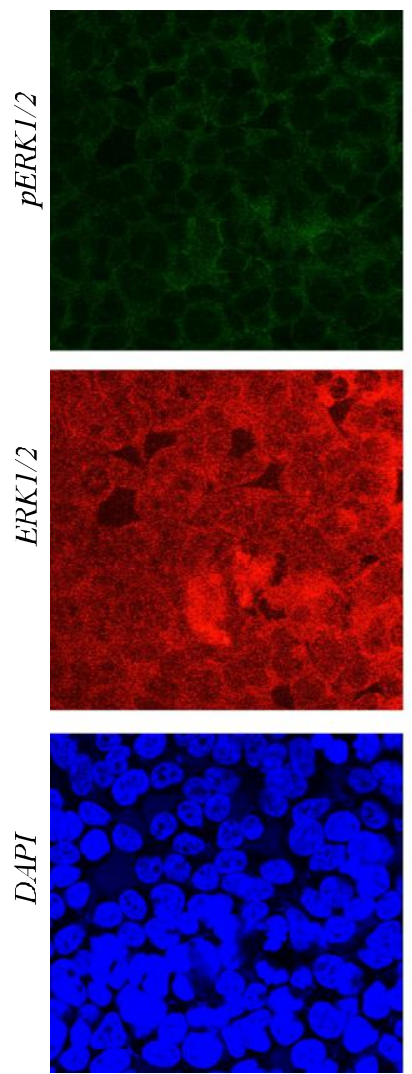

$293 \_$cDNA3.1 cells
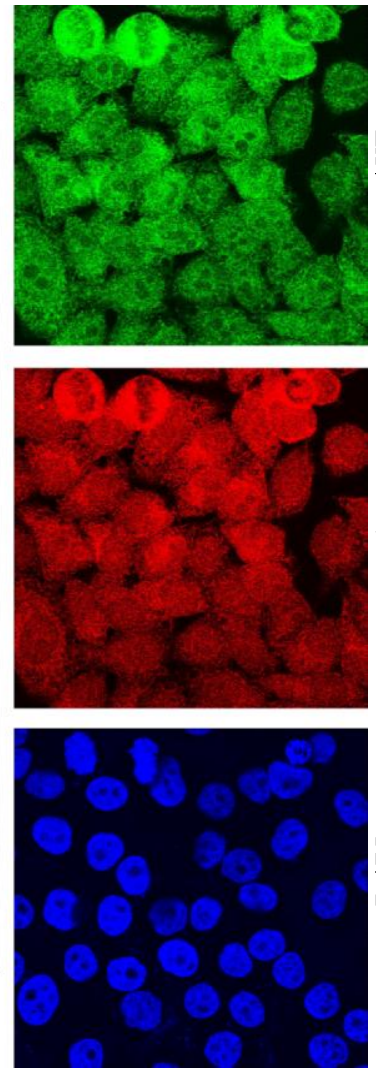

293_CHI3L1 cells
$C$
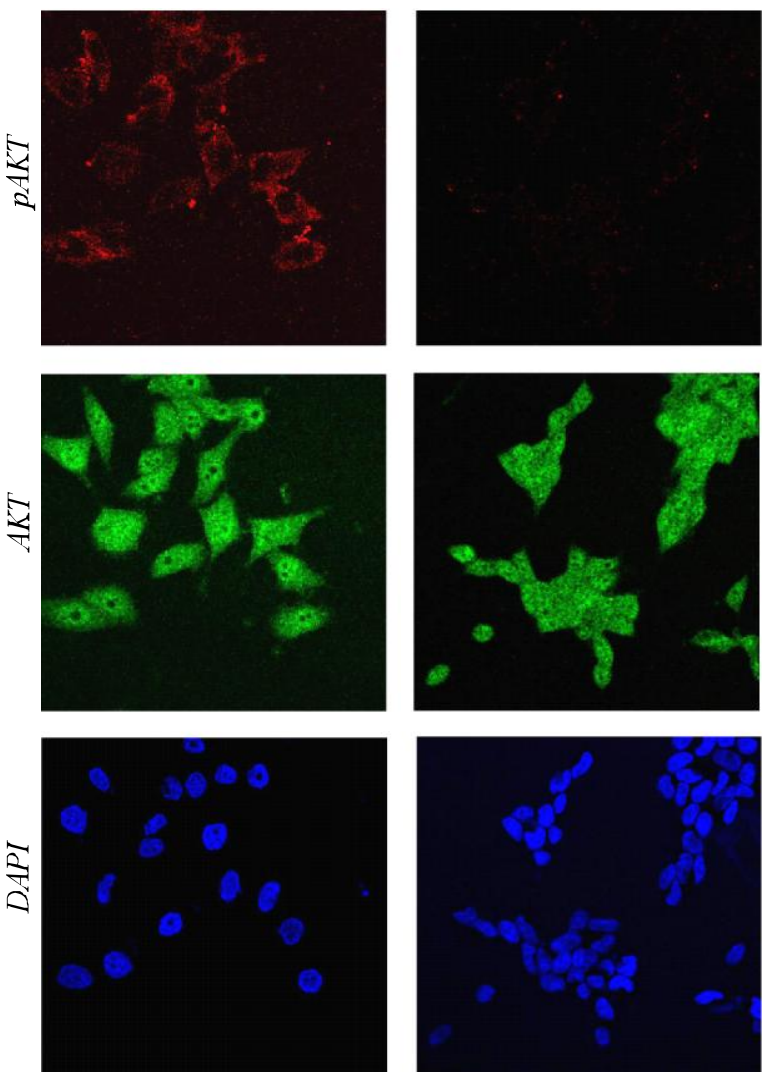

293_CHI3L1 cells

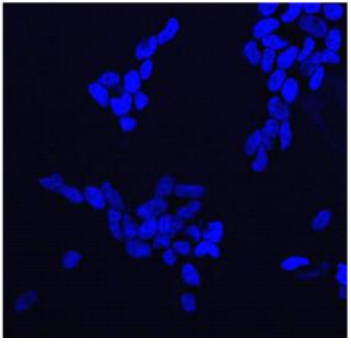

293 pcDNA3.1 cells 